\title{
New Anastomosis Groups, AG-T and AG-U, of Binucleate Rhizoctonia spp. Causing Root and Stem Rot of Cut-Flower and Miniature Roses
}

\author{
Mitsuro Hyakumachi, Achmadi Priyatmojo, Mayumi Kubota, and Hirokazu Fukui
}

First and third authors: Laboratory of Plant Pathology, Faculty of Applied Biological Sciences, Gifu University, 1-1 Yanagido, Gifu 5011193, Japan; second author: Department of Entomology and Plant Pathology, Faculty of Agriculture, Gadjah Mada University, Yogyakarta 55281, Indonesia; and fourth author: Laboratory of Horticulture, Faculty of Applied Biological Sciences, Gifu University, Japan. Accepted for publication 3 March 2005.

\begin{abstract}
Hyakumachi, M., Priyatmojo, A., Kubota, M., and Fukui, H. 2005. New anastomosis groups, AG-T and AG-U, of binucleate Rhizoctonia spp. causing root and stem rot of cut-flower and miniature roses. Phytopathology 95:784-792.

Root and stem rot of cut-flower roses (Rosa spp.) was observed in commercial glasshouse-grown roses in 10 prefectures of Japan from 1998 through 2001. Binucleate-like Rhizoctonia spp. were isolated mainly from the disease plants. In all, 670 isolates were divided into two types based on cultural appearance; 168 isolates of light brown to brown type and 502 isolates of whitish type. A hyphal anastomosis reaction using representative isolates from each type revealed that the light brown to brown type belonged to anastomosis group G (AG-G), whereas the whitish type (AG-CUT) failed to anastomose with tester strains of binucleate Rhizoctonia AG-A through AG-S. Neither isolates of AG-G nor AG-CUT anastomosed with tester strains of a previously reported unknown AG

entiate AG-CUT and AG-MIN from known AGs of binucleate Rhizoctonia spp., restriction fragment length polymorphism (RFLP) and sequence analyses of a ribosomal (r)DNA internal transcribed spacer (ITS) region were conducted. Among the eight restriction enzymes used, HaeIII produced DNA banding patterns for AG-CUT that differed from those of tester strains and AG-MIN. Additionally, restriction profiles of AG-MIN differed from those of all tester strains. AG-G isolates from cut-flower roses had the same RFLP pattern as the tester strains of AG-G. Based on the results of hyphal anastomosis and RFLP and sequence analysis of an rDNA-ITS region, we propose that AG-CUT be designated AG-T and AG-MIN be designated AG-U, two new AGs of binucleate Rhizoctonia spp. The phylogenetic tree based on the sequence data of the rDNA-ITS region showed that isolates of AG-MIN were in a distinct clade from other AGs, whereas isolates of AG-CUT were in the same clade as those of AG-A. More detailed phylogenetic analysis besides rDNA-ITS region might be necessary for AG classification of binucleate Rhizoctonia spp.
\end{abstract} (AG-MIN) of binucleate Rhizoctonia spp. collected from miniature roses. In pathogenicity tests, randomly selected isolates of the three groups caused root and stem rot on cut-flower and miniature roses. To differ-
Additional keyword: differentiation.

and RAPD analyses (39). The results of fatty acid analysis also support the grouping of AG-Q as a subset of AG-D (I) (34).

In Japan, cut-flower roses (Rosa spp.) are cultivated in many prefectures and have an economic value of approximately $\$ 251$ million, which represented $8.2 \%$ of the wholesale value of cut flowers in 1999 (21). They are commonly grown using a soilless rockwool culture system in glasshouses for the domestic market. Among the species of cut-flower roses, Rosa odorata is commonly used as rootstock because of its resistance to many root pathogens, fast root growth, and few thorns.

Between 1999 and 2001, root and stem rot were observed in commercially grown cut-flower roses in 10 prefectures in Japan. Primary symptoms included rapidly expanding lesions on roots, with infected roots turning dark brown or black. Stems also were infected and turned dark reddish brown or black as disease progressed (Fig. 1). Wilting of leaves was observed as a result of severe root and stem rot and mycelia often observed in rockwool slabs. Binucleate-like Rhizoctonia spp. were isolated consistently from the diseased roots and stems.

Although Rhizoctonia spp. have been reported as major pathogens that cause severe economic damage on many species of ornamental plants (7), there are no previous reports on cut-flower roses. The only published study relating to Rhizoctonia spp. on ornamental roses is on miniature roses in Japan. Binucleate Rhizoctonia spp. and $R$. solani (AG-2-2 IIIB and AG-4 HG-I) have been associated with root and stem rot of miniature roses (35). These isolates of a binucleate Rhizoctonia sp. failed to

DOI: 10.1094/PHYTO-95-0784

(C) 2005 The American Phytopathological Society 
anastomose with any tester strains of binucleate Rhizoctonia AGA through AG-S (35). Pathogenicity of this binucleate Rhizoctonia sp. on cut-flower roses has not yet been investigated, and pathogenicity of binucleate-like Rhizoctonia spp. obtained from cut-flower roses on miniature roses remains unknown.

Polymorphisms in DNA sequences, such as RFLPs of the rDNA-ITS or large rRNA subunit region, have been widely used for characterization and identification of Rhizoctonia spp. (10, $14,20,33,35,39,40)$. Compared with conventional criteria, such as cultural morphology, hyphal anastomosis, and morphology of teleomorphs (36), RFLP of the rDNA-ITS region can provide quick, reliable, and repeatable results (20). AG-D (I) and AG-D (II) were distinguished from $12 \mathrm{AG}$ tester strains of binucleate Rhizoctonia spp. after digestion with enzymes EcoRI, HaeIII, HhaI, HinfI, and MboI (39). Cubeta et al. (10) conducted RFLP analysis of a large rRNA subunit region and discriminated among 13 of 21 AGs of binucleate Rhizoctonia spp. using enzymes HhaI, HpaII, Sau3AI, and TaqI. Furthermore, Kuninaga et al. (17) differentiated potato and tobacco strains of $R$. solani AG-3 using sequence data of the rDNA-ITS region.

The objective of this study was to characterize isolates of a binucleate-like Rhizoctonia sp. associated with root and stem rot of cut-flower roses by describing (i) their anastomosis reactions among known AGs of binucleate Rhizoctonia spp., (ii) nuclear
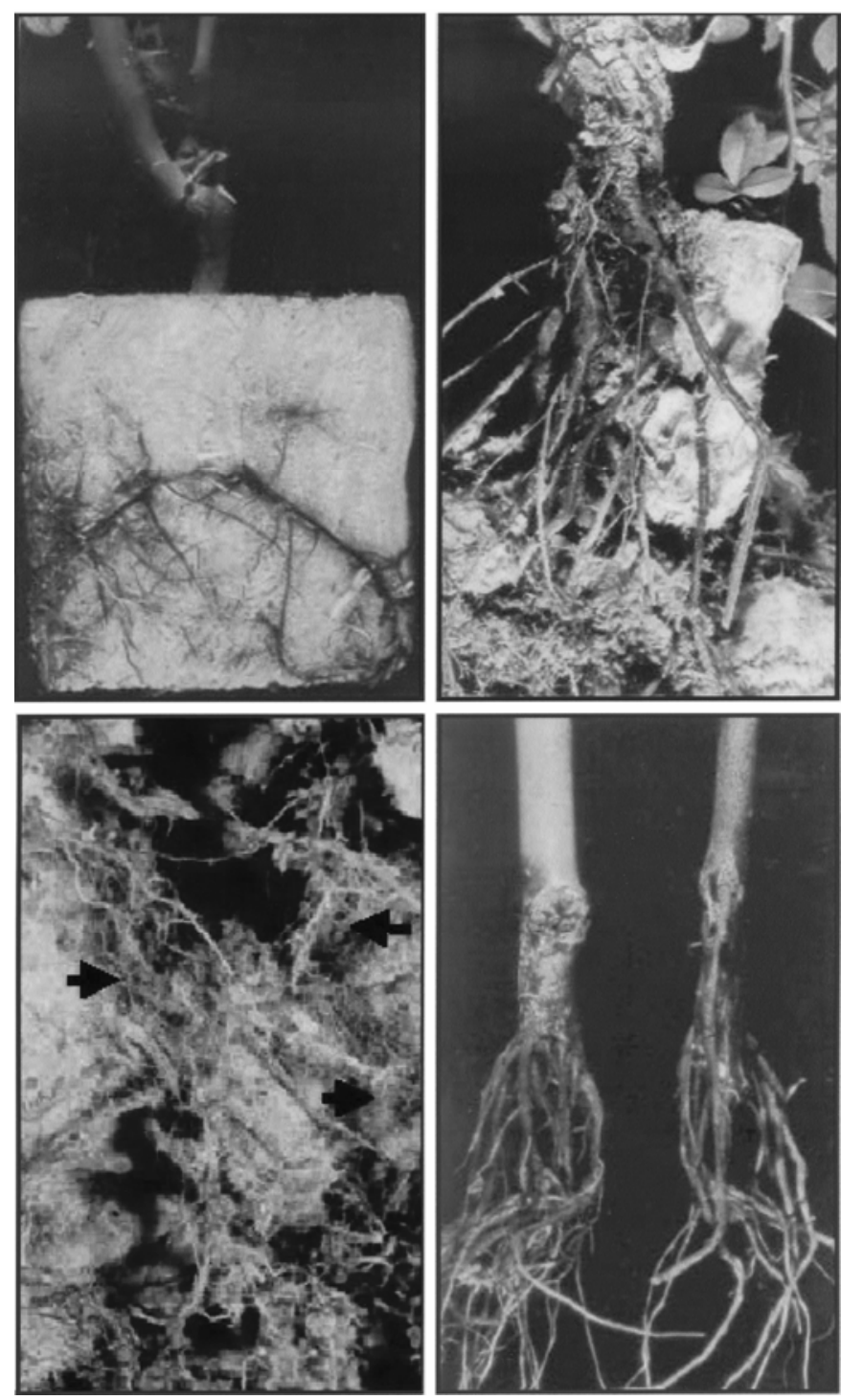

Fig. 1. Root and stem rot of cut-flower roses caused by binucleate Rhizoctonia spp. conditions, (iii) mycelial growth rate, (iv) colony morphology (potato dextrose agar [PDA]), (v) virulence on cut-flower and miniature roses, and (vi) RFLP pattern and sequence data of an rDNA-ITS region. Isolates of a binucleate Rhizoctonia sp. from miniature roses (35) also were included in anastomosis determination, RFLP and sequence analyses of the rDNA-ITS region, and virulence determination.

\section{MATERIALS AND METHODS}

Fungal isolation and culture maintenance. Cut-flower rose samples were collected from commercial glasshouse-grown roses in 10 prefectures (Oita, Fukuoka, Wakayama, Kyoto, Shiga, Gifu, Aichi, Shizuoka, Niigata, and Ibaraki) in Japan in 1999, 2000, and 2001 (Fig. 2). All cut-flower roses were grown in a rockwool culture system. Infected roots and stems were washed thoroughly in running tap $\mathrm{H}_{2} \mathrm{O}$ for $30 \mathrm{~min}$ to remove adhered rockwool particles, air dried, and cut into $5-\mathrm{mm}$ pieces. Roots and stems were surface disinfected in $0.5 \% \mathrm{NaOCl}$ for $2 \mathrm{~min}$ and rinsed three times in sterile distilled $\mathrm{H}_{2} \mathrm{O}$. Pieces of root and stem were dried on sterilized filter papers and placed on petri dishes (five segments per plate) containing acidified water agar ( $\mathrm{pH} 4.5)$. Cultures were incubated for 2 to 3 days at $25^{\circ} \mathrm{C}$ in the dark. Colonies with characteristics typical of Rhizoctonia spp. were hyphaltipped and placed onto PDA (Becton, Dickinson and Company, Sparks, MD). Pure cultures were stored at $25^{\circ} \mathrm{C}$ in PDA slant tubes amended with streptomycin sulfate and penicillin $\mathrm{G}$ (Nacalai Tesque, Inc., Kyoto, Japan) at $50 \mathrm{mg} / \mathrm{liter}$ each or on autoclaved barley grains at $4{ }^{\circ} \mathrm{C}$. From cut-flower roses, there were two cultural types (light brown to brown and whitish) of a binucleate-like Rhizoctonia sp. In all, 670 isolates were obtained, with 168 and 502 isolates belonging to the former and latter cultural types, respectively. Three isolates from each location and two of each colony morphology type were selected as representative isolates, except from Aichi prefecture, where only one isolate showing light brown to brown type was selected (Table 1). As a result, 47 isolates of a binucleate Rhizoctonia sp. from cut-flower roses (12 light brown to brown and 35 whitish types selected from different prefectures) and 5 isolates of a binucleate Rhizoctonia sp. from miniature roses (35), hereinafter-named AG-MIN, were used for following experiments; these isolates are listed in Table 1.

Nuclear condition. The number of nuclei per hyphal cell in each isolate from roots and stems of cut-flower roses listed in

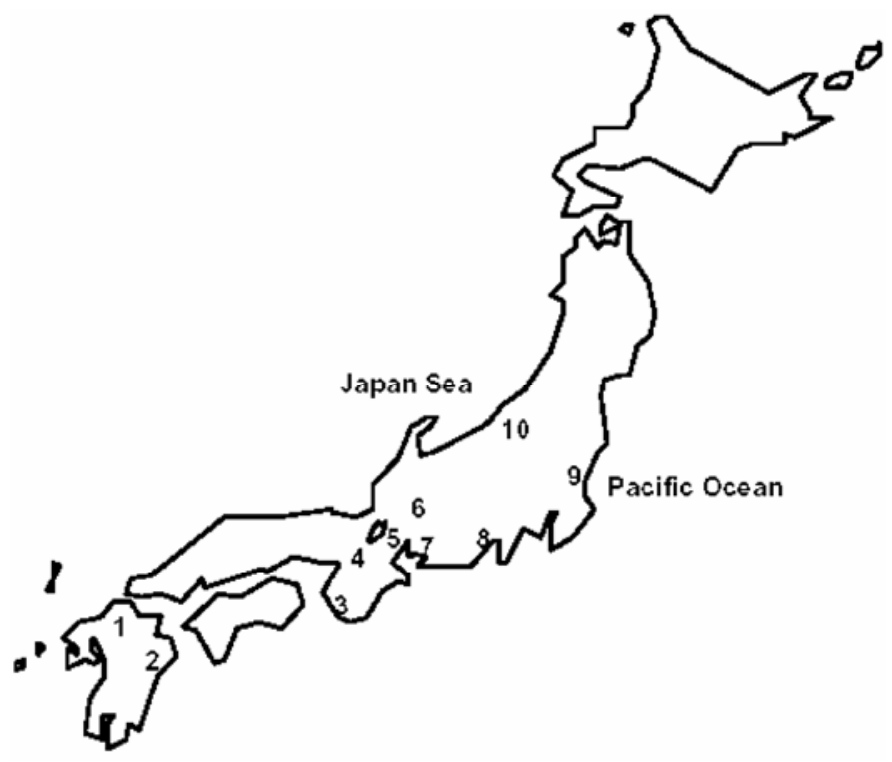

Fig. 2. Locations where root and stem rot of cut-flower roses were observed in Japan. 1, Fukuoka; 2, Oita; 3, Wakayama; 4, Kyoto; 5, Shiga; 6, Gifu; 7, Aichi; 8, Shizuoka; 9, Ibaraki; and 10, Niigata prefectures. 
Table 1 was determined by the procedure of Kronland and Stanghellini (16). Agar disks (7 $\mathrm{mm}$ in diameter) containing mycelium from 2- to 3-day-old cultures growing on PDA were placed on clean, sterile, glass slides and incubated in a moist chamber at $25^{\circ} \mathrm{C}$ for 2 to 3 days in the dark. Nuclei were stained with safranin $\mathrm{O}$ and $3 \% \mathrm{KOH}$ (5). The number of nuclei were determined using bright field microscopy at $\times 400$.

AG determination. In all, 10 of 12 isolates of light brown to brown type, 27 of 35 isolates of whitish type, and 2 isolates of AG-MIN were used in AG determination (Table 1). Agar disks
(7 $\mathrm{mm}$ in diameter) cut from the perimeter of 2- to 3-day-old cultures of each isolate on PDA were placed on sterilized glass slides coated with a very thin layer of water agar. These disks were paired with tester strains of binucleate Rhizoctonia AG-A through AG-S, except AG-J and AG-M (Table 2). In addition, two isolates of AG-MIN (MWR22 and MWR26) were paired with representative isolates from cut-flower roses and the same set of tester strains (Tables 1 and 2). Slides were put in a moist chamber and incubated at $25^{\circ} \mathrm{C}$ in the dark. When the hyphae from the two disks were overlapping (after $\approx 2$ or 3 days of incubation),

TABLE 1. Isolates of binucleate Rhizoctonia from cut-flower and miniature roses used in this study

\begin{tabular}{|c|c|c|c|c|c|c|c|c|c|}
\hline \multirow[b]{2}{*}{ Isolate } & \multirow[b]{2}{*}{ Cultural type $(A G)^{t}$} & \multirow[b]{2}{*}{$\mathrm{A}^{\mathrm{u}}$} & \multirow[b]{2}{*}{$G^{v}$} & \multirow[b]{2}{*}{$\mathrm{V}^{\mathrm{w}}$} & \multirow[b]{2}{*}{$\mathrm{R}^{\mathrm{x}}$} & \multirow[b]{2}{*}{$\mathrm{S}^{\mathrm{y}}$} & \multirow[b]{2}{*}{ Origin } & \multicolumn{2}{|c|}{ Host } \\
\hline & & & & & & & & Species & Cultivar \\
\hline 1Shi-1299 & LB-B (AG-G) & $\mathrm{O}^{\mathrm{z}}$ & $\mathrm{o}$ & $\mathrm{o}$ & o & $\mathrm{o}$ & Shizuoka & Rosa odorata & Pretty Woman \\
\hline 1Shi-1299a & LB-B (AG-G) & o & $\ldots$ & $\ldots$ & $\ldots$ & $\ldots$ & Shizuoka & R. odorata & Pretty Woman \\
\hline 10Shi-1299 & LB-B (AG-G) & o & $\ldots$ & $\ldots$ & $\ldots$ & $\ldots$ & Shizuoka & R. odorata & Pretty Woman \\
\hline 10Shi-1299a & LB-B (AG-G) & $\ldots$ & $\ldots$ & $\ldots$ & $\ldots$ & $\ldots$ & Shizuoka & $R$. odorata & Pretty Woman \\
\hline 4Wak-600 & LB-B (AG-G) & $\mathrm{o}$ & $\mathrm{o}$ & o & $\mathrm{o}$ & o & Wakayama & R. odorata & Not known \\
\hline 4Wak-600a & LB-B (AG-G) & o & $\ldots$ & $\ldots$ & $\ldots$ & $\ldots$ & Wakayama & R. odorata & Not known \\
\hline 4Wak-600b & LB-B (AG-G) & o & $\ldots$ & $\ldots$ & $\ldots$ & $\ldots$ & Wakayama & $R$. odorata & Not known \\
\hline 4Aic-201 & LB-B (AG-G) & o & $\ldots$ & o & $\ldots$ & $\ldots$ & Aichi & R. multiflora & Lady Violet \\
\hline 20 it -800 & LB-B (AG-G) & $\mathrm{o}$ & $\mathrm{o}$ & $\ldots$ & $\mathrm{o}$ & & Oita & R. odorata & Not known \\
\hline 20 it $-800 b t$ & LB-B (AG-G) & $\mathrm{o}$ & $\ldots$ & $\ldots$ & $\ldots$ & $\ldots$ & Oita & R. odorata & Not known \\
\hline 3 Oit- 800 & LB-B (AG-G) & $\mathrm{o}$ & $\ldots$ & $\ldots$ & $\ldots$ & $\ldots$ & Oita & $R$. odorata & Not known \\
\hline 60 it- 800 & LB-B (AG-G) & $\ldots$ & $\ldots$ & o & $\ldots$ & $\ldots$ & Oita & R. odorata & Not known \\
\hline Gif-1999 & W (AG-CUT) & o & o & o & $\mathrm{o}$ & $\ldots$ & Gifu & Roza multiflora & Little Mabel \\
\hline Gif-1999a & W (AG-CUT) & $\mathrm{o}$ & $\ldots$ & $\ldots$ & $\ldots$ & $\ldots$ & Gifu & R. multiflora & Little Mabel \\
\hline Gif-1999b & W (AG-CUT) & o & $\ldots$ & $\ldots$ & $\ldots$ & $\ldots$ & Gifu & R. multiflora & Little Mabel \\
\hline 2Shi-1999 & $\mathrm{W}(\mathrm{AG}-\mathrm{CUT})$ & $\mathrm{o}$ & $\mathrm{o}$ & $\ldots$ & $\mathrm{o}$ & $\mathrm{o}$ & Shizuoka & R. odorata & Pretty Woman \\
\hline 3Shi-1999 & W (AG-CUT) & $\mathrm{o}$ & $\ldots$ & $\ldots$ & $\ldots$ & $\ldots$ & Shizuoka & R. odorata & Pretty Woman \\
\hline 4Shi-1999 & W (AG-CUT) & o & $\ldots$ & $\ldots$ & $\ldots$ & $\ldots$ & Shizuoka & R. odorata & Pretty Woman \\
\hline 5Shi-1999a & W (AG-CUT) & $\ldots$ & $\ldots$ & $\ldots$ & $\ldots$ & $\ldots$ & Shizuoka & R. odorata & Pretty Woman \\
\hline 5Shi-1999b & W (AG-CUT) & $\ldots$ & $\ldots$ & $\ldots$ & $\ldots$ & $\ldots$ & Shizuoka & R. odorata & Pretty Woman \\
\hline 5Shi-1999c & W (AG-CUT) & $\ldots$ & $\ldots$ & $\ldots$ & $\ldots$ & $\ldots$ & Shizuoka & $R$. odorata & Pretty Woman \\
\hline 5Shi-1999d & W (AG-CUT) & $\ldots$ & $\ldots$ & $\ldots$ & $\ldots$ & $\ldots$ & Shizuoka & R. odorata & Pretty Woman \\
\hline 13Куо-1999 & W (AG-CUT) & $\mathrm{o}$ & $\ldots$ & o & $\mathrm{o}$ & $\ldots$ & Kyoto & $R$. odorata & Not known \\
\hline 13 Куо-1999а & W (AG-CUT) & o & $\ldots$ & $\ldots$ & $\ldots$ & $\ldots$ & Kyoto & R. odorata & Not known \\
\hline 13 Kyo- $1999 \mathrm{~b}$ & W (AG-CUT) & $\mathrm{o}$ & $\ldots$ & $\ldots$ & $\ldots$ & $\ldots$ & Kyoto & $R$ odorata & Not known \\
\hline Aic- 400 & W (AG-CUT) & o & o & o & $\mathrm{o}$ & o & Aichi & R. multiflora & Lady Violet \\
\hline Aic-500 & W (AG-CUT) & o & $\ldots$ & $\ldots$ & $\ldots$ & $\ldots$ & Aichi & R. multiflora & Lady Violet \\
\hline Aic-500a & W (AG-CUT) & $\mathrm{O}$ & $\ldots$ & $\ldots$ & $\ldots$ & $\ldots$ & Aichi & R. multiflora & Lady Violet \\
\hline Aic- $500 b$ & W (AG-CUT) & $\ldots$ & $\ldots$ & $\ldots$ & $\ldots$ & $\ldots$ & Aichi & R. multiflora & Lady Violet \\
\hline Aic-500c & W (AG-CUT) & $\ldots$ & $\ldots$ & $\ldots$ & $\ldots$ & $\ldots$ & Aichi & R. multiflora & Lady Violet \\
\hline 2 Oit-600 & W (AG-CUT) & o & o & o & $\ldots$ & $\ldots$ & Oita & R. odorata & Akabo Rote \\
\hline 50 it- 600 & W (AG-CUT) & o & $\ldots$ & $\ldots$ & $\ldots$ & $\ldots$ & Oita & R. odorata & Akabo Rote \\
\hline 40 it -800 & $\mathrm{~W}(\mathrm{AG}-\mathrm{CUT})$ & $\mathrm{o}$ & $\ldots$ & $\ldots$ & $\mathrm{o}$ & o & Oita & R. odorata & Akabo Rote \\
\hline $50 i t-800$ & W (AG-CUT) & $\ldots$ & $\ldots$ & $\ldots$ & $\ldots$ & $\ldots$ & Oita & $R$. odorata & Akabo Rote \\
\hline 1Fuk-600 & W (AG-CUT) & $\mathrm{o}$ & $\ldots$ & $\mathrm{o}$ & $\mathrm{o}$ & o & Fukuoka & $R$. odorata & Not known \\
\hline 2Fuk-600 & W (AG-CUT) & o & $\ldots$ & $\ldots$ & $\ldots$ & $\ldots$ & Fukuoka & R. odorata & Not known \\
\hline 3 Fuk-600 & W (AG-CUT) & o & $\ldots$ & $\ldots$ & $\ldots$ & $\ldots$ & Fukuoka & R. odorata & Not known \\
\hline 1 Nig-600 & $\mathrm{W}(\mathrm{AG}-\mathrm{CUT})$ & o & $\ldots$ & o & $\mathrm{o}$ & $\ldots$ & Niigata & R. odorata & Not known \\
\hline 1Nig2-600 & $\mathrm{W}(\mathrm{AG}-\mathrm{CUT})$ & o & $\ldots$ & $\ldots$ & $\ldots$ & $\ldots$ & Niigata & $R$. odorata & Not known \\
\hline 2Nig2-600 & W (AG-CUT) & $\mathrm{o}$ & $\ldots$ & $\ldots$ & $\ldots$ & $\ldots$ & Niigata & R. odorata & Not known \\
\hline 1Shig-600 & W (AG-CUT) & o & $\ldots$ & $\ldots$ & $\mathrm{o}$ & $\ldots$ & Shiga & R. odorata & Pretty Woman \\
\hline 1Shig-600a & W (AG-CUT) & o & $\ldots$ & $\ldots$ & $\ldots$ & $\ldots$ & Shiga & R. odorata & Pretty Woman \\
\hline 1Shig-600b & W (AG-CUT) & o & $\ldots$ & $\ldots$ & $\ldots$ & $\ldots$ & Shiga & R. odorata & Pretty Woman \\
\hline 5Shig-1299 & $\mathrm{W}(\mathrm{AG}-\mathrm{CUT})$ & $\ldots$ & $\cdots$ & o & $\ldots$ & $\cdots$ & Shiga & R. odorata & Pretty Woman \\
\hline 3Iba-1000 & W (AG-CUT) & o & o & $\ldots$ & o & o & Ibaraki & R. odorata & Not known \\
\hline 3Iba-1000a & $\mathrm{W}(\mathrm{AG}-\mathrm{CUT})$ & $\mathrm{o}$ & $\ldots$ & $\ldots$ & $\ldots$ & $\ldots$ & Ibaraki & $R$. odorata & Not known \\
\hline 3Iba-1000b & W (AG-CUT) & o & $\ldots$ & $\ldots$ & $\ldots$ & $\ldots$ & Ibaraki & R. odorata & Not known \\
\hline MWR-20 & AG-MIN & $\ldots$ & $\ldots$ & $\ldots$ & $\mathrm{o}$ & $\mathrm{o}$ & Gifu & R. hybrida & Silk \\
\hline MWR-21 & AG-MIN & $\ldots$ & $\ldots$ & $\ldots$ & $\ldots$ & $\ldots$ & Gifu & R. hybrida & Silk \\
\hline MWR-22 & AG-MIN & o & $\ldots$ & o & o & o & Gifu & R. hybrida & Silk \\
\hline MWR-24 & AG-MIN & $\ldots$ & $\ldots$ & $\ldots$ & $\mathrm{o}$ & $\mathrm{O}$ & Gifu & R. hybrida & Silk \\
\hline MWR-26 & AG-MIN & o & $\ldots$ & o & $\ldots$ & $\ldots$ & Gifu & R. hybrida & Silk \\
\hline
\end{tabular}

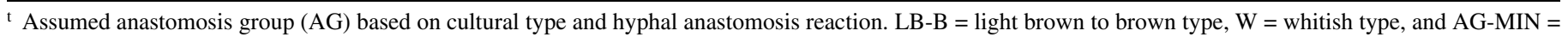
binucleate Rhizoctonia isolate obtained from miniature roses (35).

u Hyphal anastomosis test was conducted.

${ }^{v}$ Hyphal growth rate was determined.

${ }^{w}$ Virulence was determined.

${ }^{x}$ Restriction fragment length polymorphism analysis of ribosomal DNA internal transcribed spacer (rDNA-ITS) region was conducted.

y Sequence analysis of rDNA-ITS region was conducted.

${ }^{\mathrm{z}}$ Isolate used for the indicated test or analysis. 
they were stained with $0.5 \%$ aniline blue in lactophenol and examined microscopically to determine anastomosis reactions. Reactions were placed into one of four categories according to Carling (8).

Radial growth rates. Growth rates of randomly selected isolates (three and five isolates of whitish and light brown to brown types, respectively, from cut-flower roses) (Table 1) were determined at $5,10,15,20,25,28,30,35$, and $40^{\circ} \mathrm{C}$. Agar disks ( $7 \mathrm{~mm}$ in diameter) containing mycelium from the margin of a 2- to 3-day-old colony were transferred to PDA in a 9-cmdiameter petri dish. Colony radius was measured until a colony reached the edge of the petri dish. Treatments were replicated three times and the experiment was repeated once.

Virulence determination. Virulence of 11 randomly selected isolates from cut-flower roses (four light brown to brown type and 7 whitish type) (Table 1) and two randomly selected AG-MIN isolates (MWR-22 and MWR-26) were evaluated on cut-flower rose $(R$. odorata cv. Pretty Woman) and miniature rose ( $R$. hybrida cv. Silk). Inoculum of these isolates was prepared by growing each isolate in a 500-ml Erlenmeyer flask containing $100 \mathrm{~g}$ of barley grain and $100 \mathrm{ml}$ of distilled water. Flasks were sterilized at $121^{\circ} \mathrm{C}$ for $20 \mathrm{~min}$ and inoculated with three 7-mm-diameter mycelial disks of the isolates cut from the edges of 3-day-old isolates growing on PDA. Flasks were incubated at $25^{\circ} \mathrm{C}$ for 10 days in the dark and shaken regularly to aid uniform colonization. Infested barley grain was air dried for 1 week and stored at $4^{\circ} \mathrm{C}$ until needed. After rooting for 6 weeks, plants of uniform size were transplanted into 6 -cm-diameter plastic pots containing $100 \mathrm{~g}$ of Rhizoctonia-infested soil mixture ( $2 \mathrm{~g}$ of infested barley grains plus $98 \mathrm{~g}$ of soil mixture). The soil mixture contained peat moss, perlite, vermiculite, sandy loam soil, and rice hulls $(55: 23: 15: 5: 2, \% \mathrm{wt})$, and was pasteurized at $60^{\circ} \mathrm{C}$ for $30 \mathrm{~min}$ on two consecutive days prior to use. The soil mixture amended with sterile barley grains served as a control. Plants were incubated in a glasshouse at 28 to $30^{\circ} \mathrm{C}$. Virulence was determined 4 weeks after inoculation on a 0 -to- 4 scale where $0=$ healthy, no rot on root and stem; 1 = light root and stem rot; 2 = moderate root and stem rot; 3 = severe root and stem rot; and $4=$ dead plant. Treatments were arranged in a randomized complete block design with five replicates of each treatment. Treatment means were separated with Fisher's protected least significant differences (FLSD) at $P=$ 0.05 . Data containing 0 values were square root transformed before analysis (11). The experiment was repeated once.

RFLP of rDNA-ITS analysis. Genomic DNA from representative isolates (three isolates of light brown to brown type, nine isolates of whitish type, three isolates of AG-MIN, and all the tester

TABLE 2. Tester isolates of binucleate Rhizoctonia used in this study

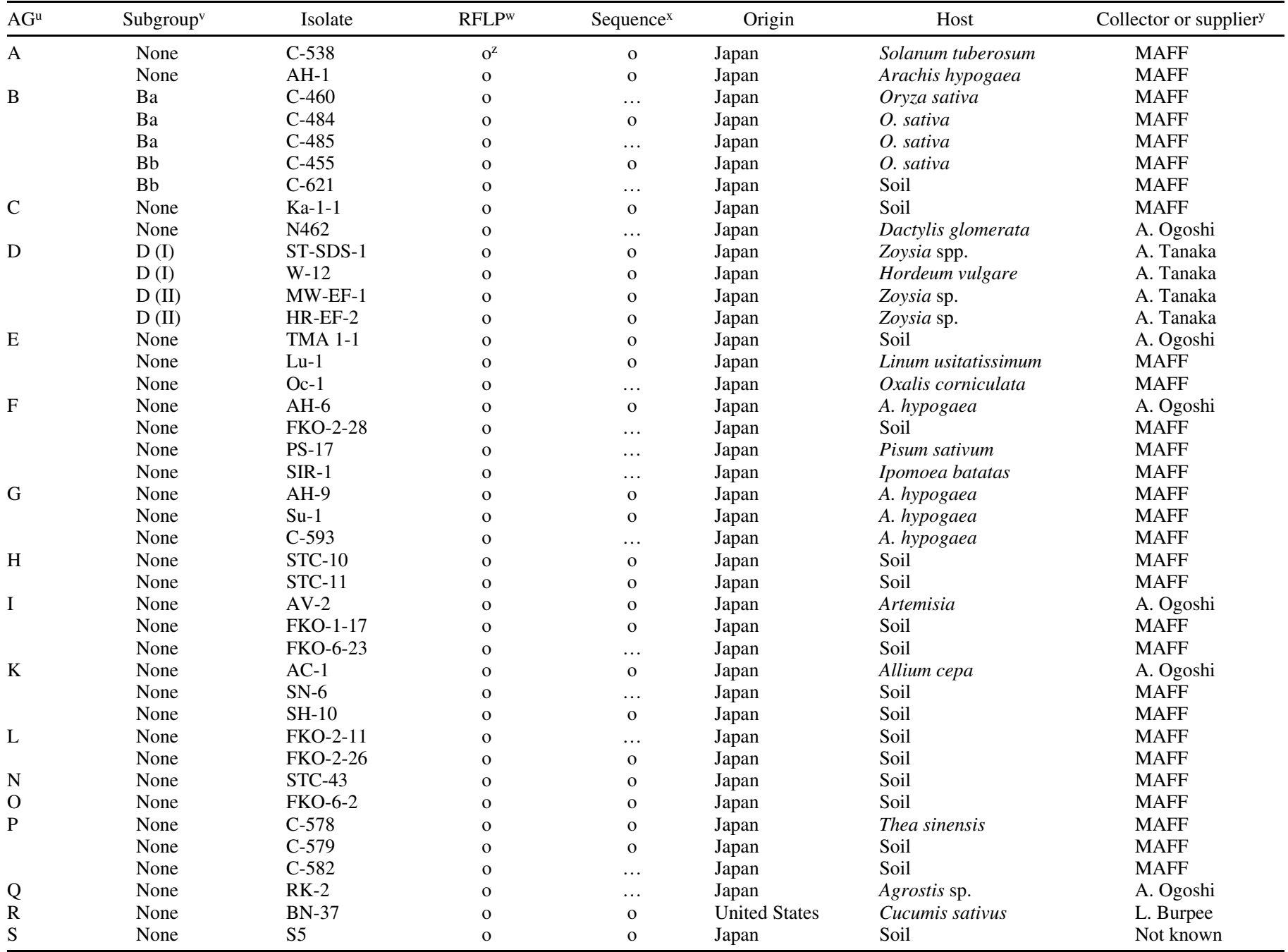

u AG = anastomosis group; AG-Q was identified as AG-D (I) on the basis of RFLP of rDNA-ITS and RAPD analyses (39).

${ }^{v}$ None $=$ subgroups either do not exist or have not been designated.

${ }^{\text {w }}$ Restriction fragment length polymorphism (RFLP) analysis of ribosomal DNA internal transcribed spacer (rDNA-ITS) region was conducted.

${ }^{x}$ Sequence analysis of rDNA-ITS region was conducted.

${ }^{y}$ MAFF $=$ Ministry of Agriculture, Forestry and Fishery, Japan.

${ }^{\mathrm{z}}$ Isolate used for the indicated test or analysis. 
strains from known binucleate Rhizoctonia AGs) (Tables 1 and 2) were obtained using a modification of a boiling miniprep procedure $(22,23)$. Briefly, isolates were grown in petri dishes containing $20 \mathrm{ml}$ of potato dextrose broth (PDB; Becton, Dickinson and Company) at $25^{\circ} \mathrm{C}$ in the dark for 3 to 7 days depending on their growth rate. After washing with distilled $\mathrm{H}_{2} \mathrm{O}$ three times in a Buchner funnel, mycelium was blotted between two Whatman No. 1 filter papers. Approximately $5 \mathrm{mg}$ of mycelium was removed with a sterile needle and placed into a $1.5-\mathrm{ml}$ microfuge tube containing $0.5 \mathrm{ml}$ of sterile distilled $\mathrm{H}_{2} \mathrm{O}$. The tube was boiled for $5 \mathrm{~min}$ and kept at room temperature for $15 \mathrm{~min}$ prior to long-term storage at $-20^{\circ} \mathrm{C}$. Genomic DNA was extracted with the procedure of Lee and Taylor (19) when DNA could not be obtained by the boiling miniprep method. The universal oligonucleotide primers ITS 1 and ITS4 were used to amplify the ITS regions (41). Reactions were performed in a final volume of $50 \mu \mathrm{l}$ in an automated thermal cycler (Perkin-Elmer Cetus Instruments, Norwalk, CT). The reaction mixture contained $50 \mathrm{pmol}$ of each primer, 1.25 units of Taq polymerase, $100 \mathrm{mM}$ dNTP mixture, and $1 \times$ polymerase chain reaction $(\mathrm{PCR})$ buffer $(10 \mathrm{mM}$ Tris$\mathrm{HCl}, \mathrm{pH}$ 8.3, $50 \mathrm{mM} \mathrm{KCl}$, and $15 \mathrm{mM} \mathrm{MgCl}_{2}$ ) (Takara Shuzo Co., Ltd., Kusatsu, Japan), and approximately $200 \mathrm{ng}$ of fungal DNA. The reaction mixture was overlaid with one drop of mineral oil
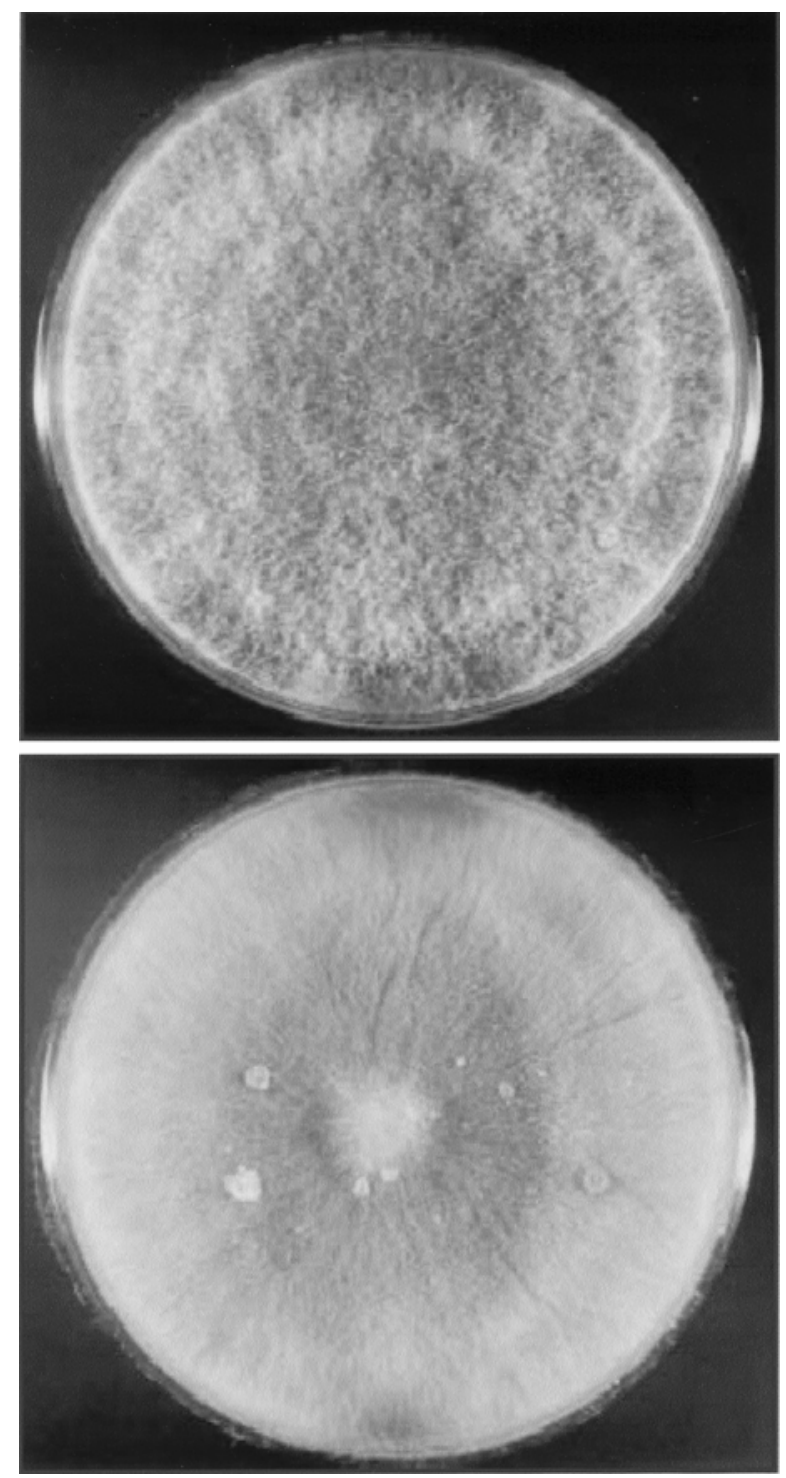

Fig. 3. Cultural morphology of binucleate Rhizoctonia anastomosis group (AG)-CUT (top) and AG-G (bottom) isolated from cut-flower roses after 25 days of incubation on potato dextrose agar in the dark. prior to PCR and amplification was carried out at $94^{\circ} \mathrm{C}$ for $3 \mathrm{~min}$; followed by 30 cycles at $94^{\circ} \mathrm{C}$ for $1 \mathrm{~min}, 59^{\circ} \mathrm{C}$ for $1 \mathrm{~min}$, and at $72^{\circ} \mathrm{C}$ for $2 \mathrm{~min}$; with the final extension at $72^{\circ} \mathrm{C}$ for $3 \mathrm{~min}$. Amplification products were washed with $50 \mu \mathrm{l}$ of chloroform, precipitated with $5 \mu \mathrm{l}$ of $3 \mathrm{M}$ sodium acetate and $125 \mu \mathrm{l}$ of $95.5 \%$ $\mathrm{EtOH}$ at $-80^{\circ} \mathrm{C}$ for $30 \mathrm{~min}$, and centrifuged. Pellets were dried under vacuum, resuspended in $25 \mu \mathrm{l}$ of Tris-EDTA buffer, and stored at $4{ }^{\circ} \mathrm{C}$ until used. Amplification products were electrophoretically separated through a $2 \%$ agarose gel (Takara Shuzo Co., Ltd.) and visualized under UV light after staining with ethidium bromide. A molecular marker (100-bp DNA ladder; Life Technologies Inc., Gaithersburg, MD) was used as reference in each gel. Aliquots of all amplification reactions were digested separately with restriction enzymes EcoRI, HinfI, MboI, HaeIII, HincII, HapII, HhaI, and TaqI in accordance with the manufacturer's recommendations (Takara Shuzo Co. Ltd.). After electrophoresis through 3\% NuSieve 3:1 agarose gel (Cambrex Bio Science, Rockland, ME) in Tris-acetate-EDTA buffer, digestion products were observed under UV light after staining with ethidium bromide. A molecular marker (25- and 100-bp DNA ladder; Life Technologies Inc.) was used as a reference in each gel.

Sequencing of rDNA-ITS region. Sequence of the rDNA-ITS region from representative isolates ( 2 isolates of light brown to brown type, 5 isolates of whitish type, 3 isolates of AG-MIN, and 27 isolates of tester strains from known binucleate Rhizoctonia AGs) (Tables 1 and 2) were determined. Sequencing was done using Big Dye Terminator (version 3.1; Applied Biosystems, Tokyo) according to the manufacturer's instructions. An automated thermal cycler (Perkin-Elmer Cetus Instruments, Norwalk, CT) was used for the PCR sequencing reaction and sequences were determined using an Applied Biosystems prism 3100 DNA sequencer (Perkin-Elmer Applied Biosystems). Additional rDNAITS sequence data were obtained from the GenBank nucleotide sequence database. The primer sequences for ITS1 and ITS4 were removed and the remaining sequence data were analyzed using Clustal W version 1.81 (38) at the DNA Data Bank of Japan. Alignment gaps were treated as missing data and the aligned sequences were analyzed by the neighbor joining method for the phylogenetic tree construction. A distance analysis was performed using Kimura 2-parameter correction. The strength of the tree branches was tested by 1,000 bootstrap trials. Alignments and data analysis have been deposited in TreeBASE (accession no. S1294).

\section{RESULTS}

Fungal isolation and nuclear number. In all, 670 isolates of binucleate-like Rhizoctonia spp. were collected from diseased roots and stems of cut-flower roses from 10 Japanese prefectures during the 3-year study period. From colony morphology, these isolates were divided into two types; 168 isolates of light brown to brown type and 502 isolates of whitish type. Forty seven representative isolates from these two types were observed to be all binucleate; no multinucleate Rhizoctonia isolates were obtained from either diseased roots or stems.

Anastomosis grouping, colony morphology, and isolation frequency. Isolates having the whitish colony type (AG-CUT) (Fig. 3) failed to anastomose with any binucleate Rhizoctonia tester. This morphological type was collected in Fukuoka, Oita, Wakayama, Kyoto, Shiga, Gifu, Aichi, Shizuoka, Niigata, and Ibaraki prefectures, but not in Wakayama. Isolates associated with AG-CUT did not form sclerotia on PDA. Isolates having the light brown to brown colony (Fig. 3) were collected in Aichi, Shizuoka, Oita, and Wakayama prefectures and gave the C2 anastomosis reaction with AG-G tester strains and formed sclerotia on PDA. The isolation frequency of AG-G and AG-CUT varied between locations (Fig. 4). The isolation frequency of AG-CUT was higher than AG-G in Aichi and Oita prefectures, whereas the 
isolation frequency of AG-G was higher in Shizuoka prefecture. Pairings among AG-G isolates collected from cut roses produced C3 (anastomosing and adjacent cells were not killed) or C2 anastomosis reaction when the paired isolates were collected from the same and different locations, respectively. Similar results also were observed when pairing among isolates within AG-CUT. Isolates of AG-G did not anastomose (C0) with isolates of AG-CUT in any pairing. Neither isolates of AG-G nor AG-CUT anastomosed with tester isolates of AG-MIN (MWR22 or MWR26). Based on anastomosis reaction of the representative isolates of light brown to brown type (AG-G) and whitish type (AG-CUT) from different locations, 168 and 502 isolates belonged to AG-G and AG-CUT, respectively.

Hyphal growth rates. Average growth rates of three isolates from AG-G and five isolates from AG-CUT were compared (Fig. 5). Isolates of AG-G and AG-CUT had similar hyphal growth rates at different temperatures except at $35^{\circ} \mathrm{C}$, where $A G-G$ grew faster than AG-CUT. Both isolates of AG-G and AG-CUT had an optimum growth rate at $28^{\circ} \mathrm{C}$ and very slow growth at $10^{\circ} \mathrm{C}$; growth was absent at 5 and $40^{\circ} \mathrm{C}$.

Virulence determination. Experiments were conducted twice and similar results were obtained between these experiments. The result from the first trial is shown in Table 3. Isolates of AG-G collected from cut-flower roses (1Shi-1299, 4Wak-600, 4Aic-201, and 6Oit-800), AG-CUT (Gif-1999, 13Kyo-1999, 1Nig-600, 2Oit-600, Aic-400, 1Fuk-600, and 5Shi-1299), and AG-MIN (MWR22 and MWR26) caused root and stem rot that produced from moderate to heavy damage on cut-flower and miniature rose

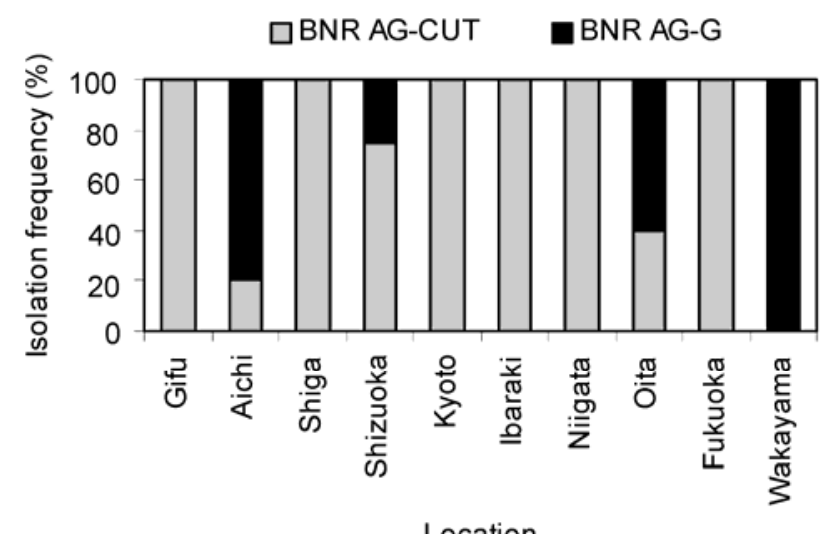

Fig. 4. Isolation frequency of binucleate Rhizoctonia spp. obtained from root and stem rot of cut-flower roses in 10 prefectures. Samples were collected from 1999 through 2001.

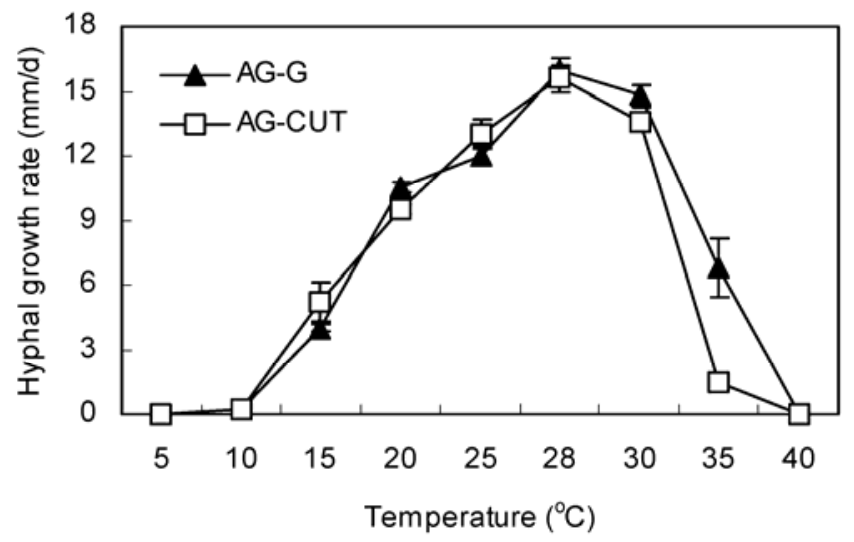

Fig. 5. Effect of temperature on growth of isolates of binucleate Rhizoctonia spp. obtained from cut-flower roses. Isolates were grown on potato dextrose agar in the dark. Bar shows a standard error. plants (Table 3). Symptoms caused by the three groups were undistinguishable. Additionally, the symptoms produced in the laboratory were similar to those observed on diseased plants collected from the fields. The binucleate Rhizoctonia AGs were reisolated from the artificially inoculated plants, completing Koch's postulates. No symptoms were observed on control plants.

RFLP of rDNA-ITS. The primers ITS 1 and ITS 4 amplified a product from the ITS region of each isolate of binucleate Rhizoctonia spp. used in this study. The length of the rDNA-ITS region of all the isolates of AG-G and AG-CUT was estimated as $0.66 \mathrm{~kb}$, whereas those of AG-MIN were $\approx 0.68 \mathrm{~kb}$. The restriction enzyme digest patterns of PCR-amplified rDNA-ITS using enzymes EcoRI, TaqI HinfI, HincII, HaeIII, MboI, HhaI, and HapII had the same sized products among isolates within each group but differed from group to group (Table 4). The PCR products were not cleaved by enzyme HincII except for those from isolates associated with AG-G, which had two restriction fragments. Enzyme HapII digested the PCR products of all isolates tested, with the exception of those associated with AG-C, AG-D (I), AG-I, and AG-K. Two restriction fragments were observed for templates digested with EcoRI or HhaI. Variation in the pattern of restriction fragments was observed using enzymes HinfI, HaeIII, or MboI. Of the eight restriction enzymes used, HaeIII showed the most distinct banding patterns when comparing AG-CUT to AG-MIN and other known AGs. Isolates of AG-G collected from cut-flower roses had the same banding patterns as those of AG-G tester isolates (Table 4).

Sequencing of rDNA-ITS region. Of 37 isolates, the rDNAITS region was successfully sequenced for 31 isolates, but sequencing of the remaining 6 isolates ( 2 of AG D (II), 2 of AG-E, and 1 each of AG-N and AG-O) was unsuccessful. The phylogenetic tree produced after comparing the nucleotide positions generally grouped the isolates to AG (Fig. 6). However, isolates belonging to different AGs, such as AG-I and AG-L, as well as AG-CUT and AG-A were in the same clade. Conversely, isolates belonging to the same AG, such as AG-F and AG-I, were in different clades. The isolates of AG-MIN that were examined were grouped in the same clade, separate from other AGs. Isolates of

TABLE 3. Virulence of binucleate Rhizoctonia isolates on cut-flower rose (Rosa odorata cv. Pretty Woman) and miniature rose $\left(R\right.$. hybrida cv. Silk) ${ }^{\mathrm{x}}$

\begin{tabular}{|c|c|c|}
\hline \multirow[b]{2}{*}{$\mathrm{AG}$, isolate $^{\mathrm{y}}$} & \multicolumn{2}{|c|}{ Disease scale ${ }^{z}$} \\
\hline & Cut-flower & Miniature \\
\hline \multicolumn{3}{|l|}{ AG-G } \\
\hline 1Shi-1299 & $2.8 \mathrm{c}$ & $2.6 \mathrm{~b}$ \\
\hline 4Wak-600 & $3.0 \mathrm{c}$ & $3.6 \mathrm{c}$ \\
\hline 4Aic-201 & $4.0 \mathrm{~d}$ & ND \\
\hline 6 Oit-800 & $2.2 \mathrm{~b}$ & ND \\
\hline \multicolumn{3}{|l|}{ AG-CUT } \\
\hline Gif-1199 & $2.4 \mathrm{~b}$ & $3.0 \mathrm{~b}$ \\
\hline 13Куо-1999 & $4.0 \mathrm{~d}$ & $3.3 \mathrm{~b}$ \\
\hline 1Nig-600 & $1.6 \mathrm{~b}$ & $2.6 \mathrm{~b}$ \\
\hline 20 it-600 & $3.2 \mathrm{c}$ & $3.6 \mathrm{c}$ \\
\hline Aic-400 & $4.0 \mathrm{~d}$ & $3.3 \mathrm{~b}$ \\
\hline 1Fuk-600 & $3.4 \mathrm{~d}$ & $2.6 \mathrm{~b}$ \\
\hline 5Shig-1299 & $2.2 \mathrm{~b}$ & ND \\
\hline \multicolumn{3}{|l|}{ AG-MIN } \\
\hline MWR-22 & $4.0 \mathrm{~d}$ & $4.0 \mathrm{c}$ \\
\hline MWR-26 & $4.0 \mathrm{~d}$ & $4.0 \mathrm{c}$ \\
\hline Control & $0.0 \mathrm{a}$ & $0.0 \mathrm{a}$ \\
\hline
\end{tabular}

x Plants were inoculated after rooting for 6 weeks.

y $\mathrm{AG}=$ anastomosis group. AG-G and AG-CUT are groups of binucleate Rhizoctonia spp. isolated from root and stem rot of cut-flower rose. AM-MIN is a group of binucleate Rhizoctonia spp. isolated from miniature rose.

${ }^{\mathrm{z}}$ Disease assessed on a scale ranging from 0 to 4 , in which $0=$ no disease symptom and $4=$ plant dead. Numbers are means of five replicates. Values in the same column followed by the same letter are not significantly different according to Fisher's protected least significant differences $(P=$ 0.05); ND $=$ not determined. 
AG-G collected from cut-flower roses were in the same clade as tester strains of AG-G.

\section{DISCUSSION}

Binucleate-like Rhizoctonia spp. were isolated predominantly from symptomatic roots and stems of cut-flower roses from 10 prefectures in Japan. These binucleate-like Rhizoctonia spp. were divided into two colony morphology types, light brown to brown colony type and whitish, and each turned out to belong to binucleate Rhizoctonia AG-G and AG-CUT, respectively. The latter group did not anastomose with any tester strains of binucleate Rhizoctonia spp. Isolation frequencies of AG-G and AG-CUT were location dependent. For instance, isolates of AG-CUT were recovered frequently in Gifu, Shiga, Kyoto, Ibaraki, Niigata, and Fukuoka prefectures but much less frequently in Aichi and Oita prefectures. In contrast, AG-G but not AG-CUT was observed in Wakayama prefecture. AG-G was observed in 4 of the 10 prefectures. Isolates of AG-G infect sugar beet, bean, melon, peanut, sunflower, and strawberry $(22,24,31,36)$. The occurrence of root and stem rot of cut-flower roses caused by AG-G has not been reported previously. Mature cultures of AG-G collected from cutflower roses were similar in appearance to those of AG-G tester strains on PDA. Similarity also was confirmed by the C2 anastomosis reaction between AG-G collected from cut-flower roses and the AG-G tester strains. Isolates of AG-CUT and AG-MIN did not anastomose with each other or with tester strains of all known AGs of binucleate Rhizoctonia (AG-A through AG-S). These results indicate that AG-CUT and AG-MIN form isolated groups that are distinct from each other and from tester strains of all known AGs of binucleate Rhizoctonia. Additionally, mature cultures of both AG-CUT and AG-MIN were morphologically different from each other and from those of the tester strains of the known AGs of binucleate Rhizoctonia (data not shown). The former group did not produce sclerotia on PDA but the latter group did.

In addition to binucleate Rhizoctonia AGs, isolates of $R$. solani AG-2-2 IIIB and AG-4 HG-I have been associated with root and stem rot in miniature roses (35). However, no $R$. solani isolates were observed in diseased cut-flower roses. The differences in media used to grow roses may affect disease development; cutflower roses are grown using a rockwool culture system, whereas miniature roses are grown in a peat-based potting medium (35). The diversity in the composition of Rhizoctonia populations on cut-flower and miniature roses might be influenced by growth stage of plants, plant organs, season of sampling, and geographical location of crop production areas. Host specificity also is reported in some AGs of binucleate Rhizoctonia and $R$. solani. For example, AG-Ba and $-\mathrm{Bb}$ infect species belonging to the family Gramineae (36), AG-D (II) and R. solani AG-2-2-LP are associated with warm-season turfgrass diseases $(14,39), R$. solani AG-2-3 causes disease on soybean (26), and $R$. solani AG-3 attacks potato $(4,6,9,15)$. In this study, only a restricted number of AGs of Rhizoctonia spp. was isolated frequently from cut-flower and miniature roses. Further investigation is necessary in order to clarify whether these AGs have specificity to roses if the infested rose seedlings with these AGs were introduced from certain nursery sites to other rose-producing areas.

In addition to binucleate Rhizoctonia spp., Pythium spp. and Fusarium spp. were isolated from cut-flower roses in Aichi, Niigata, Oita, and Fukuoka prefectures and Aichi prefecture, respectively (data not shown). In Aichi prefecture, the isolation frequency of binucleate Rhizoctonia spp. was 52\%, of Pythium spp. 38\%, and of Fusarium spp. 11\%. The isolation frequency of binucleate Rhizoctonia spp. from cut-flower roses in Niigata, Oita, and Fukuoka prefectures were 95, 84, and 77\%, respec-

TABLE 4. Anastomosis grouping of binucleate Rhizoctonia, internal transcribed spacer (ITS) region, and digested fragment after treatment with restriction enzyme

\begin{tabular}{|c|c|c|c|c|c|c|c|c|c|}
\hline \multirow[b]{2}{*}{$\mathrm{AG}^{\mathrm{x}}$} & \multirow[b]{2}{*}{ ITS $(k b)^{\mathrm{y}}$} & \multicolumn{8}{|c|}{ Fragment length $(\mathrm{kb})^{\mathrm{z}}$} \\
\hline & & EcoRI & TaqI & HincII & HapII & HhaI & MboI & HinfI & HaeIII \\
\hline A & 0.66 & $0.36,0.30$ & $0.36,0.30$ & 0.66 & 0.66 & $0.33,0.33$ & $0.23,0.21,0.13$ & $0.28,0.23,0.13,0.08$ & $0.52,0.10,0.04$ \\
\hline $\mathrm{Ba}$ & 0.66 & $0.36,0.30$ & $0.36,0.30$ & 0.66 & 0.66 & $0.33,0.33$ & $0.22,0.20,0.13,0.07$ & $0.28,0.23,0.13$ & $0.43,0.12,0.11$ \\
\hline $\mathrm{C}$ & 0.64 & $0.35,0.29$ & $0.34,0.30$ & 0.64 & $\begin{array}{l}0.46,0.11 \\
0.07\end{array}$ & $0.32,0.32$ & $0.26,0.15,0.15,0.08$ & $0.28,0.21,0.15$ & $0.45,0.12,0.07$ \\
\hline D (I) & 0.66 & $0.35,0.31$ & $0.35,0.31$ & 0.66 & $0.51,0.15$ & $0.33,0.33$ & $0.26,0.26,0.14$ & $\begin{array}{l}0.30,0.13,0.11,0.06, \\
0.06\end{array}$ & $0.45,0.12,0.09$ \\
\hline $\mathrm{F}$ & 0.64 & $0.35,0.29$ & $0.34,0.30$ & 0.64 & 0.64 & $0.32,0.32$ & $0.23,0.21,0.13,0.07$ & $0.31,0.22,0.11$ & $0.40,0.14,0.10$ \\
\hline G & 0.66 & $0.36,0.30$ & $0.35,0.26$ & 0.66 & 0.66 & $0.33,0.33$ & $0.25,0.22,0.14,0.05$ & $0.34,0.32$ & $0.46,0.13,0.09$ \\
\hline $\mathrm{H}$ & 0.66 & $0.35,0.31$ & $\begin{array}{l}0.31,0.21, \\
0.14\end{array}$ & 0.66 & 0.66 & $0.33,0.33$ & $0.25,0.22,0.14,0.05$ & $0.35,0.24,0.07$ & $0.50,0.11,0.05$ \\
\hline I & 0.65 & $0.34,0.31$ & $0.35,0.30$ & 0.65 & $0.55,0.10$ & $0.33,0.33$ & $0.23,0.21,0.14,0.08$ & $0.32,0.21,0.12$ & $0.45,0.11,0.09$ \\
\hline $\mathrm{K}$ & 0.66 & $0.36,0.30$ & $0.36,0.30$ & 0.66 & $0.55,0.11$ & $0.33,0.33$ & $0.31,0.15,0.15,0.06$ & $0.31,0.22,0.11$ & $0.46,0.11,0.09$ \\
\hline $\mathrm{R}$ & 0.68 & $0.35,0.33$ & $0.36,0.32$ & 0.68 & 0.68 & $0.35,0.35$ & $0.26,0.26,0.14,0.14$ & $0.34,0.24$ & $0.52,0.16$ \\
\hline$S$ & 0.66 & $0.36,0.30$ & $0.35,0.31$ & $\begin{array}{l}0.22,0.22 \\
0.22\end{array}$ & 0.66 & $0.33,0.33$ & $0.20,0.20,0.15,0.11$ & $\begin{array}{l}0.30,0.13,0.11,0.06 \text {, } \\
0.06\end{array}$ & $0.25,0.22,0.10,0.10$ \\
\hline G & 0.66 & $0.36,0.30$ & $0.35,0.26$ & 0.66 & 0.66 & $0.33,0.33$ & $0.25,0.22,0.14,0.05$ & $0.34,0.32$ & $0.46,0.13,0.09$ \\
\hline CUT & 0.66 & $0.36,0.30$ & $0.36,0.30$ & 0.66 & 0.66 & $0.33,0.33$ & $0.25,0.22,0.14,0.05$ & $0.36,0.30$ & $0.28,0.19,0.19$ \\
\hline MIN & 0.68 & $0.36,0.32$ & $0.36,0.32$ & 0.66 & 0.66 & $0.35,0.33$ & $0.25,0.25,0.18$ & $0.35,0.35$ & $0.55,0.13$ \\
\hline
\end{tabular}

${ }^{\mathrm{x}} \mathrm{AG}=$ anastomosis group of binucleate Rhizoctonia. $\mathrm{G}$ and CUT are groups of binucleate Rhizoctonia obtained from cut-flower rose and MIN is a group of binucleate Rhizoctonia obtained from miniature rose.

y ITS length.

${ }^{\mathrm{z}}$ All estimates of fragment sizes were determined by comparison with 25- and 100-bp ladders, with measurements rounded to the nearest $0.005 \mathrm{~kb}$. This was done for purposes of comparison among isolates; the values do not reflect absolute base pair fragment sizes. 
tively, and of Pythium spp. was 5, 16, and 23\%, respectively. A binucleate Rhizoctonia sp. was the only pathogen isolated in Gifu, Shiga, Kyoto, Ibaraki, Niigata, and Fukuoka prefectures. Symptoms on rose roots caused by Pythium spp., Fusarium spp., and binucleate Rhizoctonia spp. were similar. However, infection by a binucleate Rhizoctonia sp. commonly was characterized by a darker reddish brown necrosis than those observed with Pythium or Fusarium spp. In addition, Pythium and Fusarium spp. were never isolated from the stem; however, binucleate Rhizoctonia spp. Consistently were isolated from rotting stems (data not shown).

Although virulence of isolates within AG-G and AG-CUT on either cut-flower rose cv. Pretty Woman or miniature rose cv. Silk was isolate dependent, pathogenicity tests revealed that both isolates of AG-G and AG-CUT are the causal pathogens of root and stem rot of cut-flower and miniature roses. Isolates of AG-MIN included in pathogenicity tests also caused root and stem rot with similar symptom on these cultivars. AG-G, AG-MIN, and
AG-CUT can heavily damage both cut-flower and miniature roses; therefore, careful monitoring is needed to avoid significant losses.

The restriction profiles of the rDNA-ITS region observed in this study were the same as reported by Toda et al. (39). The results confirmed the similarity of AG-G isolates from cut-flower roses with the AG-G tester strains. In contrast, isolates associated with AG-CUT had a different banding pattern, which, along with results of anastomosis tests and cultural morphology, supports the separation of AG-CUT from AG-G. The separation of AG-CUT and AG-MIN from all known AGs of binucleate Rhizoctonia spp. also was supported by RFLP analysis of the rDNA-ITS region. From these results, AG-CUT and AG-MIN are proposed as new AG-T and AG-U of binucleate Rhizoctonia, respectively.

Phylogenetic analysis of the rDNA-ITS region was further conducted in order to differentiate AG-CUT and AG-MIN from known binucleate Rhizoctonia AGs as it could successfully separate AGs of $R$. solani into different clades $(12,18)$. The phylo-

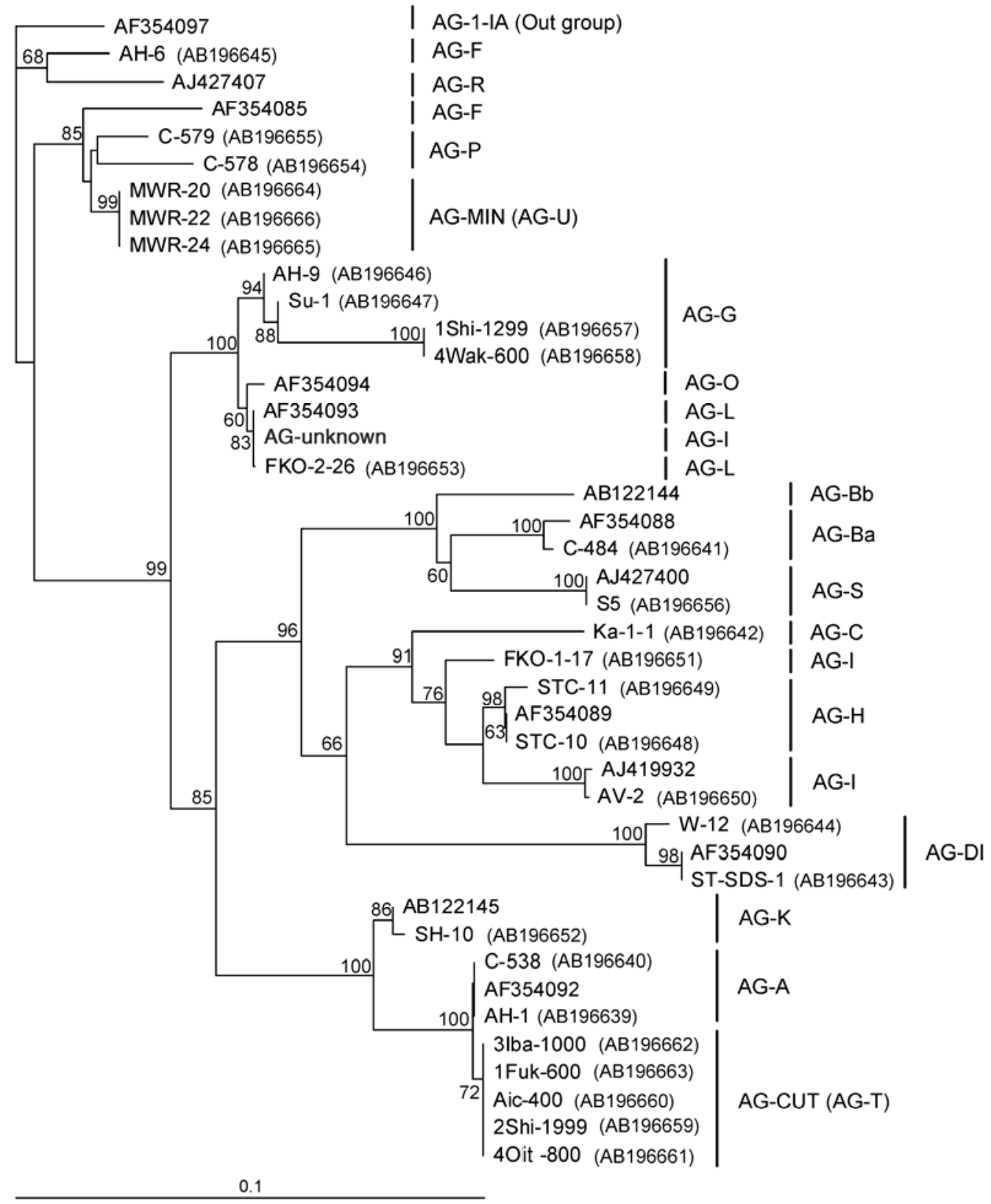

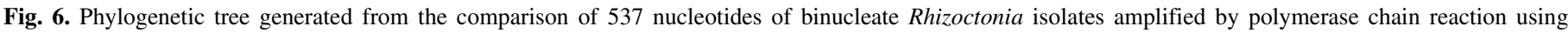

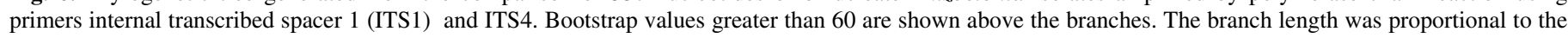
distance represented by the bar. 
genetic tree of binucleate Rhizoctonia generally grouped the isolates to AG. Isolates from AG-MIN were in different clades from other AGs; however, isolates from AG-CUT grouped with AG-A in the same clade. Gonzalez et al. (12) also reported that isolates of AG-A and AG-Bo were grouped in the same clade by the phylogenetic analysis using the same region. On the other hand, isolates belonging to the same AG, such as AG-F and AG-I, were in different clades. These contradictory results between the phylogenetic grouping and hyphal anastomosis reaction suggest that the rDNA-ITS region alone may not be suitable for AG classification. DNA data coupled with additional characters or more detailed phylogenetic analysis using sequences of other genes might be necessary in order to facilitate unambiguous identification of binucleate Rhizoctonia spp.

\section{ACKNOWLEDGMENTS}

We thank S. T. Sri Kantha for helping with the English in this article.

\section{LITERATURE CITED}

1. Adams, G. C. 1988. Thanatephorus cucumeris (Rhizoctonia solani): A species complex of wide host range. Pages 535-552 in: Advances in Plant Pathology. Vol. 6, Genetics of Plant Pathogenic Fungi. G. S. Sidhu, ed. Academic Press, New York.

2. Andersen, T. F., and Rasmussen, H. N. 1996. The mycorrhizal species of Rhizoctonia. Pages 379-390 in: Rhizoctonia Species: Taxonomy, Molecular Biology, Ecology, Pathology, and Disease Control. B. Sneh, S. Jabaji-Hare, S. Neate, and G. Dijst, eds. Kluwer Academic Publishers, Dordrecht, The Netherlands.

3. Anderson, N. A. 1982. The genetics and pathology of Rhizoctonia solani. Annu. Rev. Phytopathol. 20:329-344.

4. Bains, P. S., and Bisht, V. S. 1995. Anastomosis group identity and virulence of Rhizoctonia solani isolates collected from potato plants in Alberta, Canada. Plant Dis. 79:241-242.

5. Bandoni, R. J. 1979. Safranin O as a rapid nuclear stain for fungi. Mycologia 71:873-874.

6. Bandy, B. P., Leach, S. S., and Tavantzis, S. M. 1988. Anastomosis group 3 is the main cause of Rhizoctonia disease of potato in Maine. Plant Dis. 72:596-598.

7. Benson, D. M., and Cartwright, D. K. 1996. Ornamental diseases incited by Rhizoctonia spp. Pages 303-314 in: Rhizoctonia Species: Taxonomy, Molecular Biology, Ecology, Pathology, and Disease Control. B. Sneh, S. Jabaji-Hare, S. Neate, and G. Dijst, eds. Kluwer Academic Publishers, Dordrecht, The Netherlands.

8. Carling, D. E. 1996. Grouping in Rhizoctonia solani by hyphal anastomosis reaction. Pages 37-47 in: Rhizoctonia Species: Taxonomy, Molecular Biology, Ecology, Pathology, and Disease Control. B. Sneh, S. Jabaji-Hare, S. Neate, and G. Dijst, eds. Kluwer Academic Publishers, Dordrecht, The Netherlands.

9. Carling, D. E., and Leiner, R. H. 1986. Isolation and characterization of Rhizoctonia solani and binucleate Rhizoctonia-like fungi from aerial stems and subterranean organs of potato plants. Phytopathology 76:725-729.

10. Cubeta, M. A., Echandi, E., Abenerthy, T., and Vilgalys, R. 1991. Characterization of anastomosis groups of binucleate Rhizoctonia species using restriction analysis of ribosomal RNA gene. Phytopathology 81:1395-1400.

11. Gomez, K. A., and Gomez, A. A. 1984. Statistical Procedures for Agricultural Research. 2nd ed. John-Wiley \& Sons, New York.

12. Gonzalez, D., Carling, D. E., Kuninaga, S., Vilgalys, R., and Cubeta, M. A. 2001. Ribosomal DNA systematics of Ceratobasidium and Thanatephorus with Rhizoctonia anamorphs. Mycologia 93:1138-1150.

13. Honeycutt, E. E., and Benson, D. M. 2001. Formulation of binucleate Rhizoctonia spp. and biocontrol of Rhizoctonia solani on impatiens. Plant Dis. 85:1241-1248.

14. Hyakumachi, M., Mushika, T., Ogiso, Y., Toda, T., Kageyama, K., and Tsuge, T. 1998. Characterization of a new cultural type (LP) of Rhizoctonia solani AG 2-2 isolated from warm-season turfgrasses, and its genetic differentiation from other cultural types. Plant Pathol. 47:1-9.

15. Jager, G., and Velvis, H. 1995. Dynamics of Rhizoctonia solani (black scurf) in successive potato crops. Eur. J. Plant Pathol. 101:467-478.

16. Kronland, W. C., and Stanghellini, M. E. 1988. Clean slide technique for the observation of anastomosis and nuclear condition of Rhizoctonia solani. Phytopathology 78:820-822.

17. Kuninaga, S., Carling, D. E., Takeuchi, T., and Yokosawa, R. 2000. Comparison of rDNA-ITS sequences between potato and tobacco strains in Rhizoctonia solani AG-3. J. Gen. Plant Pathol. 66:2-11.
18. Kuninaga, S., Natsuki, T., Takeuchi, T., and Yokosawa, R. 1997. Sequence variation of the rDNA ITS regions within and between anastomosis groups in Rhizoctonia solani. Curr. Genet. 32:237-243.

19. Lee, S. B., and Taylor, J. W. 1990. Isolation of DNA from fungal mycelia and single spores. Pages 282-287 in: PCR Protocols: A Guide to Methods and Applications. M. A. Innis, D. H. Gelfand, J. J. Sninsky, and T. J. White, eds. Academic Press, San Diego, CA.

20. Liu, Z. L., and Sinclair, J. B. 1993. Differentiation of intraspecific groups within anastomosis group 1 of Rhizoctonia solani using ribosomal DNA internal transcribed spacer and isozyme comparisons. Can. J. Plant Pathol. 15:272-280.

21. MAFF. 2000. Annual Report on Japanese Agriculture FY 1999. The Ministry of Agriculture, Forestry, and Fisheries of Japan, Tokyo.

22. Martin, F. N. 2000. Rhizoctonia spp. recovered from strawberry roots in Central Coastal California. Phytopathology 90:345-353.

23. Martin, F. N., and Semer, C. R. 1997. Selection of drug-tolerant strains of Pythium sylvaticum using sublethal enrichment. Phytopathology 87:685692.

24. Martin, S. B. 1988. Identification, isolation frequency, and pathogenicity of anastomosis groups of binucleate Rhizoctonia spp. from strawberry roots. Phytopathology 78:379-384.

25. Menzeis, J. D. 1970. Introduction: The first century of Rhizoctonia solani. Pages 3-5 in: Biology and Pathology of Rhizoctonia solani. J. R. Parmeter Jr., ed. University of California Press, Berkeley.

26. Naito, S., and Kanematsu, S. 1994. Characterization and pathogenicity of a new anastomosis subgroup AG 2-3 of Rhizoctonia solani Kühn isolated from leaves of soybean. Ann. Phytopathol. Soc. Jpn. 60:681-690.

27. Ogoshi, A. 1987. Ecology and pathogenicity of anastomosis and intraspecific groups of Rhizoctonia solani Kühn. Annu. Rev. Phytopathol. 25:125-143.

28. Ogoshi, A., Oniki, M., Araki, T., and Ui, T. 1983. Anastomosis groups of binucleate Rhizoctonia in Japan and North America and their perfect states. Trans. Mycol. Soc. Jpn. 24:79-87.

29. Ogoshi, A., Oniki, M., Araki, T., and Ui, T. 1983. Studies on the anastomosis groups of binucleate Rhizoctonia and their perfect states. J. Fac. Agric. Hokkaido Univ. 61:244-260.

30. Ogoshi, A., Oniki, M., Sakai, R., and Ui, T. 1979. Anastomosis grouping among isolates of binucleate Rhizoctonia. Trans. Mycol. Soc. Jpn. 20:33-39.

31. Oniki, M., and Araki, T. 1982. Fungi isolated from brown spot of peanut pods (a new disease) and their pathogenicity. Ann. Phytopathol. Soc. Jpn. 48:84.

32. Parmeter, J. R., Jr., and Whitney, H. S. 1970. Taxonomy and nomenclature at the imperfect state. Pages 7-19 in: Biology and Pathology of Rhizoctonia solani. J. R. Parmeter Jr., ed. University of California Press, Berkeley.

33. Priyatmojo, A., Escopalao, V. E., Tangonan, N. G., Pascual, C. B., Suga, H., Kageyama, K., and Hyakumachi, M. 2001. Characterization of a new subgroup of Rhizoctonia solani anastomosis group 1 (AG 1-ID), causal agent of a necrotic leaf spot on coffee. Phytopathology 91:10541061.

34. Priyatmojo, A., Yamauchi, R., Kageyama, K., and Hyakumachi, M. 2001. Grouping of binucleate Rhizoctonia anastomosis group D (AG-D) isolates into subgroups I and II based on whole-cell fatty acid compositions. J. Phytopathol. 149:421-426.

35. Priyatmojo, A., Yotani, Y., Hattori, K., Kageyama, K., and Hyakumachi, M. 2001. Characterization of Rhizoctonia spp. causing root and stem rot of miniature rose. Plant Dis. 85:1200-1205.

36. Sneh, B., Burpee, L., and Ogoshi, A. 1991. Identification of Rhizoctonia Species. The American Phytopathological Society, St. Paul, MN.

37. Tanaka, A., Kitabayashi, H., Tani, T., and Ogoshi, A. 1994. A pathogen causing patch so-called "elephant footprint" on zoysia grasses. Ann. Phytopathol. Soc. Jpn. 60:344.

38. Thompson, J., Higgins, D., and Gibson, T. 1994. CLUSTAL W: Improving the sensitivity of Progressive multiple sequence alignment through sequence weighting, position specific gap penalties and weight matrix choice. Nucleic Acids Res. 22:4673-4580.

39. Toda, T., Hyakumachi, M., Suga, H., Kageyama, K., Tanaka, A., and Tani, T. 1999. Differentiation of Rhizoctonia AG-D isolates from turfgrass into subgroups I and II based on rDNA and RAPD analyses. Eur. J. Plant Pathol. 105:835-846.

40. Toda, T., Nasu, H., Kageyama, K., and Hyakumachi, M. 1998. Genetic identification of web-blight fungus (Rhizoctonia solani AG 1) obtained from European pear using RFLP of rDNA-ITS and RAPD analyses. Res. Bull. Fac. Agric. Gifu Univ. 63:1-9.

41. White, T. J., Bruns, T., Lee, S. B., and Taylor, J. 1990. Amplification and direct sequencing of fungal ribosomal RNA genes for phylogenetics. Pages 315-322 in: PCR Protocols: A Guide to Methods and Applications. M. A. Innis, D. H. Gelfand, J. J. Sninsky, and T. J. White, eds. Academic Press, San Diego, CA. 